Bidik

Vol. 1 No. 1 Oktober 2020

$1-12$

\title{
Pengenalan Pemakaian Tanjak Melayu Pada Mahasiswa Sastra Daerah Fakultas Ilmu Budaya
}

\author{
Ulul Azmi*, Essy Syam, Qori Islami Aris \\ Fakultas Ilmu Budaya, Universitas Lancang Kuning \\ *Email : azmi_prabela@yahoo.co.id
}

\begin{abstract}
This service aims to introduce the use of Malay tanjak to students and provide understanding and awareness about the need to know the use of Malay tanjak in daily life. Tanjak is a tradition and identity of the Malay community. Tanjak is one of the clothing accessories for men in Malay, the tanjak is used on the head as a symbol of Malay society. Tanjak has a symbol of authority among the Malay community, the higher and more complex the shape will show the higher social status of the owner. Tanjak is usually used by men when they want to go out, like a skull cap. Tanjak is commonly used by Malay people in all layers of social class, both in the form of royal support as aristocrats and lower classes of society. The development of life which is followed by the development of technology and the inclusion of foreign culture slowly shifts the existence of the use of Malay inclines. Previously, not using a hill was considered to violate adat. Therefore, the use of tanjak is a true Malay identity. The use of the Malay hill was reintroduced because many people did not know it, one of which was the use of the hill climb for sultans, commanders and ordinary people, the way to use the Malay hill was certainly very different from one another, for which students could later apply the use of the Malay bill to the community.
\end{abstract}

Keywords : Consumption, Tanjak Malay, Students

\begin{abstract}
Abstrak
Pengabdian ini bertujuan untuk mengenalan pemakaian tanjak Melayu pada mahasiswa dan memberikan pemahaman dan penyadaran tentang perlunya untuk mengetahui pemakaian tanjak Melayu dalam kehidupan sehari-hari. tanjak merupakan tradisi dan jati diri masyarakat Melayu. Tanjak merupakan salah satu aksesoris pakaian untuk lelaki di Melayu, tanjak digunakan pada bagian kepala sebagai simbol masyrakat Melayu. Tanjak memiliki lambang kewibawaan dikalangan masyarakat Melayu,semakin tinggi dan kompleks bentuknya akan menunjukkan semakin tinggi pula status sosial sipemakainya.Tanjak biasanya digunakan lelaki saat ingin pergi keluar, layaknya sebuah songkok. tanjak biasa dipakai masyarakat Melayu seluruh lapisan kelas sosial, baik lingukungan kerajaan sebagai kalangan bangsawan maupun lapisan masyarakat kelas bawah. Perkembangan kehidupan yang diikuti dengan perkembangan teknologi dan masuknya budaya luar perlahan-lahan menggeser keberadaan pemakaian tanjak Melayu, Dalam budaya Melayu, pemakaian tanjak berkait-kelindan dengan adab, dan adat. dahulu tidak memakai tanjak dianggap melanggar adat. Oleh karena itu, pemakaian tanjak merupakan identitas orang Melayu sejati. Pemakaian tanjak Melayu diperkenalkan kembali karena banyak orang tidak mengetahuinya, salah satunya adalah pemakaian tanjak dalam bagi para sultan, panglima dan masyarakat biasa, cara pemakaian tanjak Melayu ini tentulah sangat berbeda antara satu dengan yang lainnya, untuk itu para mahasiswa nantinya dapat mengaplikasikan pemakaian tanjak Melayu pada pada masyarakat.
\end{abstract}

Kata Kunci : Pemakaian, Tanjak Melayu, Mahasiswa 


\section{Pendahuluan}

Tanjak berasal dari zaman Kesultanan Melayu Melaka. Sebelum zaman itupun sudah menjadi kewajiban rakyat jelata untuk menutup kepala atau mengikat rambut panjang mereka agar terlihat rapi ketika menghadap Raja. Masyarakat Melayu Melaka mendapat ikhtiar untuk menggunakan kain panjang berbentuk segi empat yang dilipatlipat dan diikat menjadi sejenis alas kepala yang rapi untuk dipakai dalam acara resmi. Seiring berjalanya waktu ikatan kain ini lama-kelamaan makin lama makin cantik mengikut perkembangan zaman, tanjak ini banyak dimodifikasi atau diubah suai mengikut selera pemakainya. Namun, meskipun bentuk tanjak ini sudah di modifikasi, akan tetapi teknik melipatnya harus sesuai dengan sebagaimana mestinya. Tanjak ini hanya boleh di gunakan oleh kaum laki-laki, seperti selayaknya Kopiah/songkok yang hanya di gunakan oleh kaum laki-laki. (Johan Iskandar, 2018, hal : 12)

Begitu banyaknya bentuk tanjak hasil dari perkembangan zaman, namun ada tanjak yang cukup umum dan populer di masyarakat Melayu seperti tanjak Suluk/solok Timbo berasal dari negeri sembilan. Dipakai oleh pegawai atau petinggi kerajaan. Tanjak yang satu ini sangat banyak peminatnya pada masyarakat melayu khususnya masyarakat Melayu Dumai-Riau. . (Sharul Afandy, 2018, hal : 29)

Masyarakat Melayu penggunaan tanjak diwajibkan terutama bagi kaum pria. Tujuannya agar tampak rapi saat menghadap raja karena rambut pemuda saat itu panjang dan semraut. Tanjak sendiri berawal dari Kesultanan Melayu Malaka. Bahkan sebelum zaman itu penggunaan tanjak bagi rakyat jelata diwajibkan.Tanjak Melayu Malaka pada awalnya berbahan kain panjang berbentuk segi empat kemudian dilipatlipat. Seiring berjalannya waktu ikatan itu semakin cantik dan indah. Masyarakat banyak memodifikasi sesuai dengan keinginan si pemakai. Termasuk muncul motif, corak yang menandakan derajat seseorang. Motif dan corak itu setelah berkembang menjadi pembeda. Memasuki zaman kemerdekaan, kepopuleran tanjak memudar lalu digantikan dengan cepat oleh peci. Itu karena kerajaan meleburkan diri dengan Indonesia. Ditambah tidak ada pencatatan bahwa orang Melayu dahulu memang pengguna tanjak.(Putri, 2019, hal : 9)

\section{Pedekatan Pelaksanaan Program}

Kegiatan $\mathrm{I}_{\mathrm{b}} \mathrm{m}$ dilakukan kepada mahasiswa Jurusan sastra Melayu, adapun pelaksanaan kegiatan pengabdian ini secara daring dengan menggunakan aplikasi zoom meeting yang meliputi beberapa tahap sebagai berikut:

1. Pengenalan pentingnya memahami dan mengetahui pemakaian tanjak Melayu. Pada tahap ini, tim melakukan transfer informasi mengenai definisi serta pentingnya mengetahui pemakaian tanjak Melayu.

Materi yang disampaikan pada tahap ini adalah:

- Pengenalan tanjak Melayu

- Tata cara pemakaian tanjak Melayu

- Nilai-nilai yang terkandung dalam pemakaian tanjak Melayu 
2. Adapun jumlah peserta yang ikut 20 orang yang nantinya dapat menyebarkan pengetahuan kepada yang lain.

3. Pengabdian ini diharapkan dapat diaplikasikan dalam dunia pendidikan dan lingkungan tempat tinggal.

\section{Pelaksanaan Program}

Kegiatan Pengabdian ini dilaksanakan pada tanggal 4 Mei 2020 kepada mahasiswa sastra daerah Fakultas Ilmu Budaya, yang berjumlah 20 peserta secara daring. Kegiatan ini dilakukan dengan cara memberikan materi dengan memaparkan tentang cara pemakaian tanjak Melayu yang benar. Selanjutnya menguraikan nilai-niali yang ada dalam tradisi betanjak yang banyak memberikan pembelajaran dan pendidikan dalam kehidupan bermasyarakat.

Menelaah akan sejarah dan peradaban orang-orang (masyarakat) Melayu di masa lalu, betapa kita melihat mereka amat menjaga dan memperhatikan nilai-nilai dan aspek budaya dalam menjalani hidup dan kehidupan sehari-hari. Nilai-nilai dan semangat budaya seperti bidal, pantun, syair, nazam, gurindam dan lain sebagainya, selalu saja menjadi bagian yang tak terpisahkan dalam setiap ucap dan gerak mereka.Begitu pula dengan budaya atau tradisi Melayu yang digunapakai dan dijalankan dalam bermasyarakat, seperti dalam setiap perhelatan nikah kawin, dalam upacara-upacara adat dan majelis-majelis resmi lainnya di masyarakat, tak pernah sunyi dan sepi dari nuansa adat Melayu dan tradisi yang menambahkan lagi seri. Semua itu diikuti dan dilaksanakan dengan sepenuh hati, bahkan sudah menjadi darah daging dalam diri mereka yang selalu memegang teguh akan adat istiadat yang demikian indah dan menawan.

Tradisi tanjak atau bertanjak di kalangan masyarakat kita dewasa ini, sesungguhnya merupakan hal yang sangat positif dan menggembirakan sekali. Dengan membudayakan kembali seni Tanjak ini, paling tidak kita telah berupaya untuk membangkitkan kembali nilai-nilai dan tradisi yang ada. Sebuah tradisi yang pernah

menjadi ikon Melayu serta kebanggaan dalam peradaban dan ketamadunan Melayu kita yang dahulunya pernah jaya dan selalu digeruni. Sebagai definisi sederhananya, tanjak merupakan kain yang dililitkan di kepala oleh pria Melayu. Kain yang dipakai di kepala itu memiliki jenis dan ragam bentuknya. Tanjak dahulunya merupakan identitas pemuda Melayu sebagai perlambang status sosial, baik bagi kalangan bangsawan maupun masyarakat biasa.

Sejak dahulu dan hingga hari ini, tanjak yang dibuat sangat beragam coraknya. Boleh dibuat dari bahan kain yang sederhana hingga kepada kain dan corak yang sangat mewah. Hari ini kita sering melihat jika tanjak banyak dibuat dari kain songket yang mengkilat dan beragam motif yang indah. Kesemuanya menunjukkan jika tanjak yang dicipta selalu mengikut selera dan zamannya.Tidak hanya orang dewasa, tanjaktanjak yang dipakaipun turut dipakai dan disenangi oleh orang-orang tua, remaja dan bahkan anak-anak. Ada kegembiraan dan perasaan bahagia yang didapat bila sedang bertanjak. Sebab ada yang bilang dengan bertanjak membuat si pemakainya terlihat 
lebih berkharisma.bertanjak tidak hanya soal kharisma, namun lebih kepada menjaga sikap dan perilaku

Namun ada hal yang perlu diperhatikan dan patut untuk dicermati dengan bijak, bahwa bertanjak bukanlah sekadar penghias diri bagi orang yang memakainya, melainkan pula tersirat berbagai pesan-pesan moral dan terkandung nilai filosofisnya di dalamnya.

Semestinyalah bertanjak, dengan segala bentuk motif serta jenis tanjak yang dikenakan, hendaknya ia mampu dikenali dengan baik, termasuk mempelajari dan menjiwai tanjak dan seni bertanjak itu sendiri. Sebab bertanjak bukanlah sekadar untuk suka-suka, namun hakikatnya bertanjak adalah suatu simbol kehormatan diri, yang pada masa dahulu bertanjak bagi kalangan orang-orang Melayu selain merupakan bentuk memproklamirkan jati diri, juga menunjukkan eksistensi kemelayuannya dalam menjaga kemurnian tradisi dan budayanya. Menjunjung marwah bangsa dan agamanya.

Makna sederhana yang barangkali dapat kita petik dari bertanjak. Betapa budaya ini sesungguhnya menyatu dan sejalan dengan prinsip-prinsip perintah agama, yakni menjaga kehormatan diri yang dalam aktualisasinya di tengah kehidupan dimodifikasi sedemikian rupa sesuai dengan nilai-nilai budaya yang ada. Maka tidak menutup kemungkinan bila menggunakan tanjak ini terkandung pesan-pesan yang dalam, bahwa ia dapat dijadikan salah satu penyemangat diri serta bagian dan upaya yang paling sederhana dalam mencegah terjadinya perangai-perangai buruk bagi sang pemakainya. Ibarat pengingat, bahwa tak semestinya ketika bertanjak seseorang itu berperilaku yang tak senonoh. Sama halnya pula sesorang dengan songkok atau kopiah, maka tak patut perbuatannya menyalahi norma dan adat sopan santun.

Bertanjak juga dipercayai akan mampu memberikan kewibawaan tersendiri serta dampak psikologis yang sangat kuat bagi siapa saja yang memakainya, yang kemudian seridak-tidaknya berpengaruh terhadap sikap dan prilaku positif bagi pemakainya.

Menggunakan tanjak - diantaranya Tanjak Adat, dan termasuk pula tanjaktanjak kreasi yang hari ini ramai digunakan dan dimintai oleh masyarakat kita yang ada di tanah-tanah Melayu, seperti di Bengkalis, Siak, Dumai, Meranti dan daerah-daerah lainnya di Provinsi Riau, semestinya perlu didukung sedemikian rupa, sehingga dengan bertanjak kita termasuk orang-orang yang gemar menjaga tradisi, menjaga warisan budaya yang pernah ada pada diri dan bangsa kita.

Sesungguhnya amat disayangkan peninggalan kebudayaan yang sarat akan nilai sejarah dan filosofisnya ini kemudian tak dikenali lagi oleh anak-anak cucu di masamasa yang akan datang, tidak ingin mereka kelak dengan mudah dan bangganya mengadopsi dan mengenakan tradisi dan budaya-budaya luar yang sebenarnya amat bertolakbelakang dengan nilai-nilai budaya milik kita sendiri.

Pemakaian tanjak Melayu selalu menjadi masalah saat ini karena masih banyak masyarakat yang tidak paham dengan tatacara pemakaian tanjak yang merupakan aturan penting dalam kehidupan masyarakat Melayu yang menetukan orang beradat dan bersopan santun, bahkan para mahasiswa sastra daerahpun tidak luput dari 
ketidak tahuan mereka yang merupakan ujung tombak dari pengembangan Pendidikan dan budaya Melayu.

Duapuluh orang Mahasiswa yang mengikuti pengenalan pemakain Tanjak Melayu secara daring tidak ada satupun yang tahu akan tatacara penggunaan Tanjak dan nilai filosifi yang terkandung didalamnya. Bahkan mereka tidak paham kapan tanjak itu digunakan. Untuk itu pengabdian ini memaparkan tentang pemakaian tanjak yang benar.

Tanjak yang cukup umum dan populer di masyarakat melayu seperti tanjak Suluk/solok Timbo berasal dari negeri sembilan. Dipakai oleh pegawai atau petinggi kerajaan. Tanjak yang satu ini sangat banyak peminatnya pada masyarakat Melayu khususnya masyarakat Melayu Riau.

Gambar 1 Tanjak

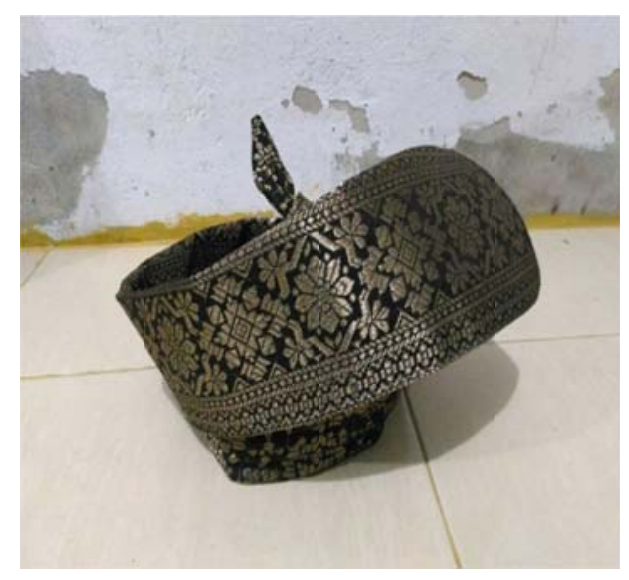

Tanjak ini dasar utamanya ada dua yaitu pertama Dilipat dan Kedua Disimpul. Tidak seperti membuat baju dipotong pola lalu di jahit satu persatu bagianya sehingga terbentuk sebuah baju. Dari selembar kain segi 4 (1 meter), di lipat menjadi bujur sangkar, atau di bagi 2 menjadi segi tiga kemudian barulah digunakan seni melipat dan menyimpul sehingga jadi sebuah tanjak.

\section{Gambar 1 Proses 1}




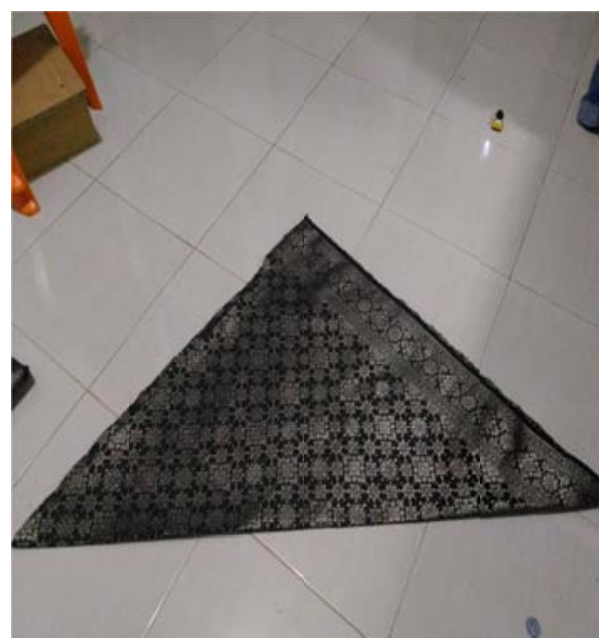

Susun 4 lipat palas yg mengarah ke bawah, khusus solok timbo menandakan pegawai kerajaan atau rakyat biasa. Lipat "bunting menantu", di depan lawi atau lambaian ibu, simpul belakang bernama "ketupat palas".

\section{a. Cara Pemakaian Tanjak}

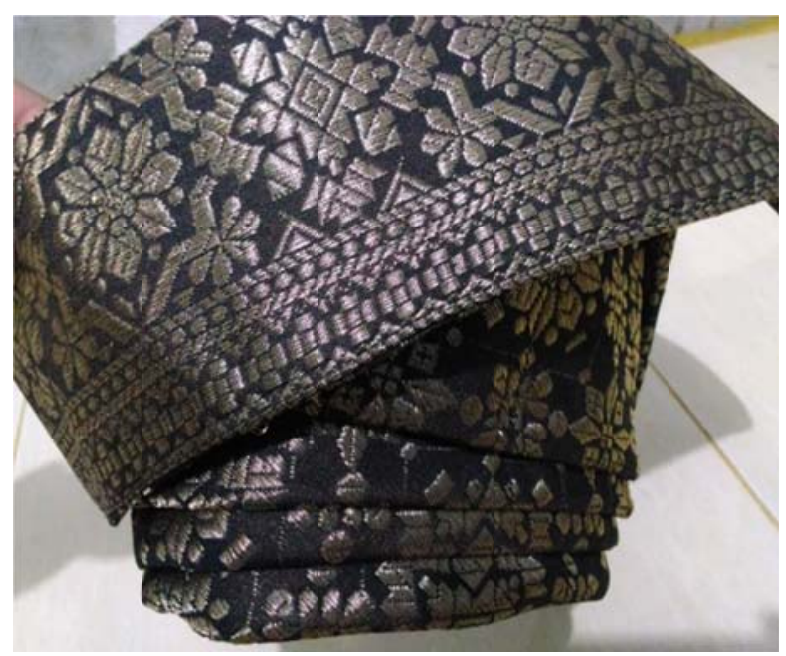

Empat Susun Lipat Kebawah disebut lipat palas 


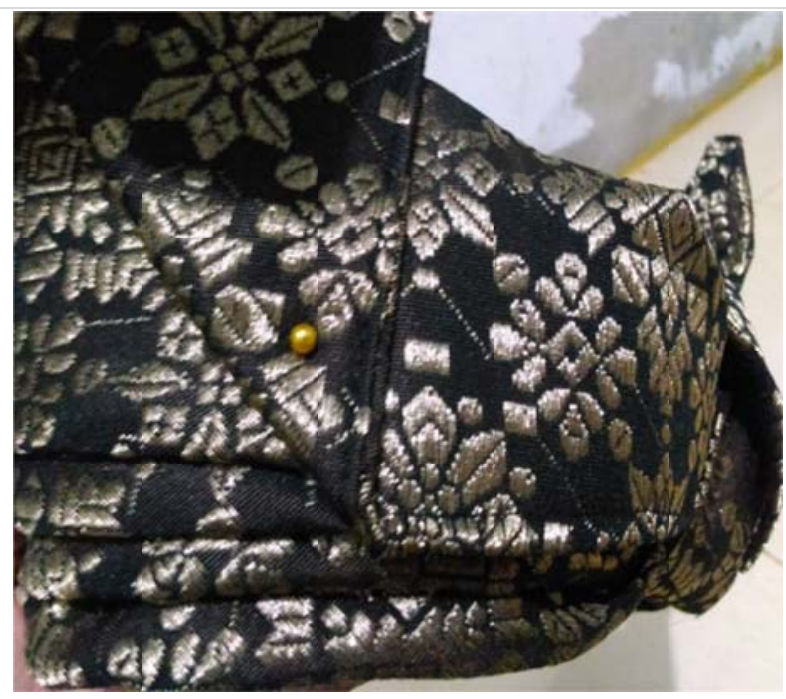

Tanjak "Dendam tak sudah" tanjak ini biasa khusus hanya di pakai oleh Sultan. Perbedaan hanya terletak pada arah lawi dan lipatnya terdapat 7 jenjang. Tanjak sultan mengarah ke kanan sedangkan "Solok Timbo" mengarah ke kiri yang biasa Digunakan pada perhelatan resmi seperti pernikahan dan acara adat lainya. Cara pemakaian tanjak yang benar dengan jarak 2 jari di atas alis kita dan memposisikan Simpul ketupat palas harus berada diatas telinga kanan kemudian lawinya otomatis akan mengarah ke kiri sampai ke bagian belakang kepala.

Tanjak untuk masyarakat biasa arah lawi kekiri dan solok timbo mengarah kearah kanan sedangkan lipatannya tidak boleh menggunakan tujuh jenjang lipatan, biasanya digunakan pada saat mengikuti acara besar seperti penobatan Datuk dan perkawinan.

Pemakaian tanjak yang lawinya mengarah kebelakang dan solok timbonya mengarah kedepan berarti pemakainya merupakan seorang pelipurlara (Penghibur) yang pada jaman dahulu merupakan orang yang memiliki talenta pandai membuat lucu (humor) untuk menghibur sultan dan para bangsawan pada masa itu. Namun apa bila lawinya mengarah kedepan dan solok timbonya mengarah kebelakang berarti suasana daerah dalam keadaan perang, tanda pemakaian ini merupakan sebuah konsep nilai filosifi keragaman yang wajib masyarakat Melayu mengetahuinya.

\section{b. Nilai Filosofi Tanjak}

Filosofi adalah sudut pandang hidup dan nilai-nilai yang dianut oleh seseorang atau suatu kelompok masyarakat. Filosofi Tanjak yang biasa digunakan masyarakat Melayu di Provinsi Riau, dijumpai bahwa setiap bentuk tanjak yang digunakan dan memiliki makna tersendiri, seperti:

Tanjak dendam tak sudah ini memiliki makna seseorang yang bekerja kerasa demi melindungi anaknya, terlihat dari bentuk-bagian atas tanjak, tidak di jahit terlihat seperti melambai-lambai.dibalik bentuk tanjakini memiliki makna kasih sayang. 

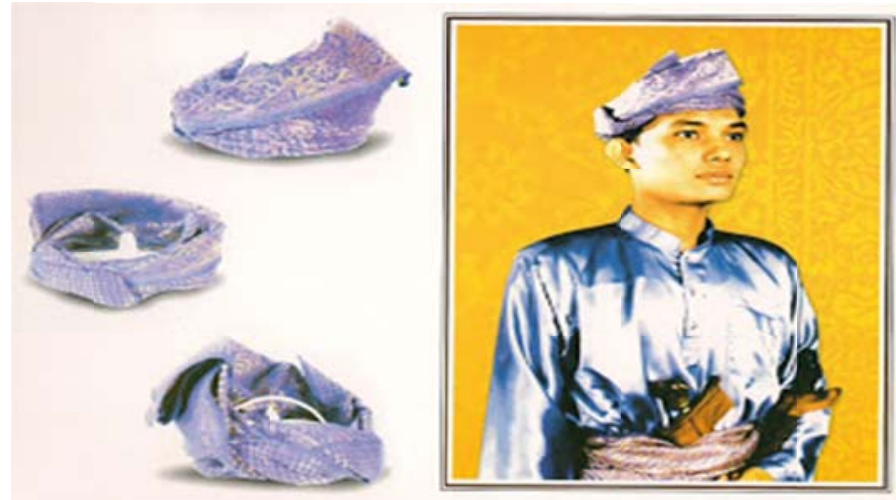

Tanjak Elang menyongsong angin memiliki filosofi kedudukan seorang raja yang menghadang musuh, melambangkan kebijaksanaan dan kecermatan, bentuk bagian atasnya seperti kepala elang yang lagi memainkan gerak angin.
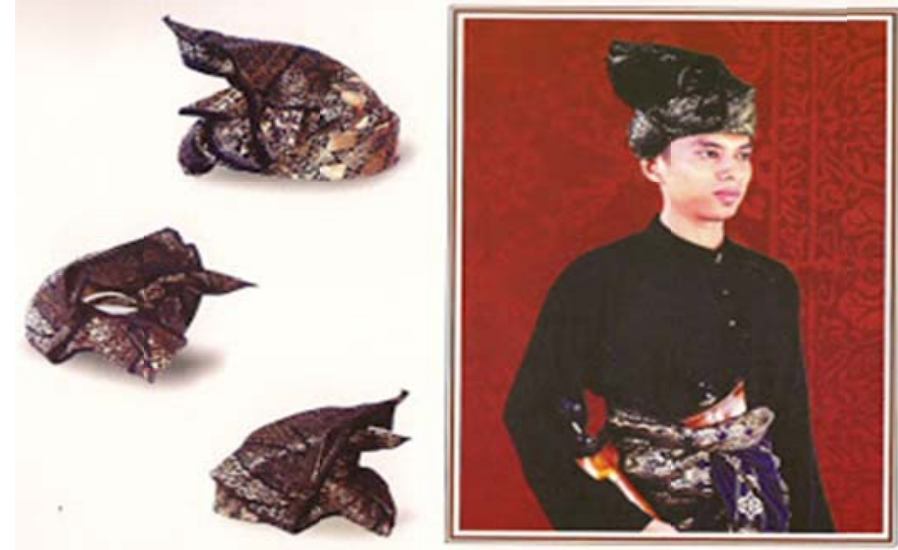

Tanjak Pial ayam adalah bentuk tanjak yang di sederhanakan dari tanjak elang menyongsong angin, pial ayam atau jengger yang berwarna merah dibagian kepala ayam memiliki makna keberaniaan.
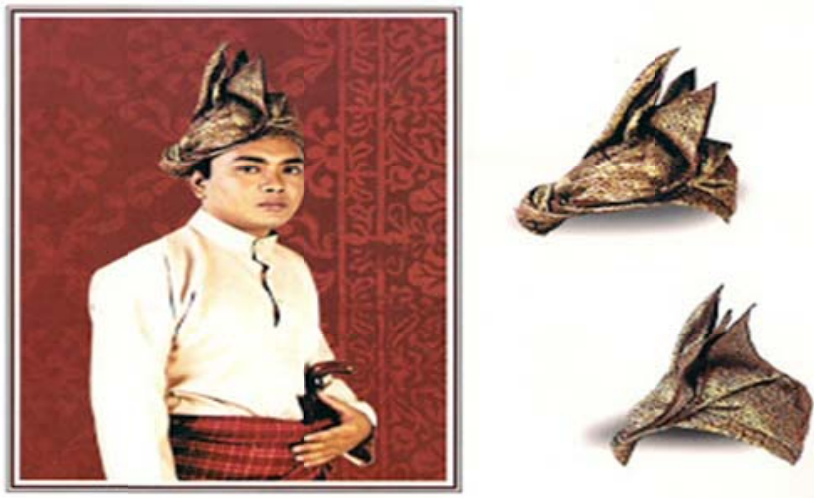

Tanjak elang patah sayap memiliki makna kesatria yang terletak dibagian lambayan atasnya yang mirip seperti kepak elang yang patah akibat perkelahian. memiliki sifat pemimpin seperti halnya seekor elang ketika harus terbang melawan badai. 

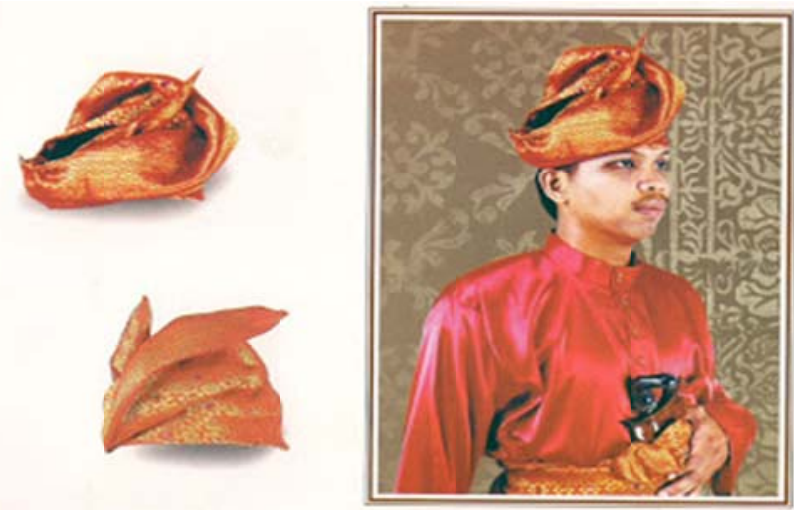

Tanjak Pari mudik dibagian atas tanjak yang di bentuk patah kebawah yang menyerupai ikan pari memiliki makna sikap rendah hati kepada sesama
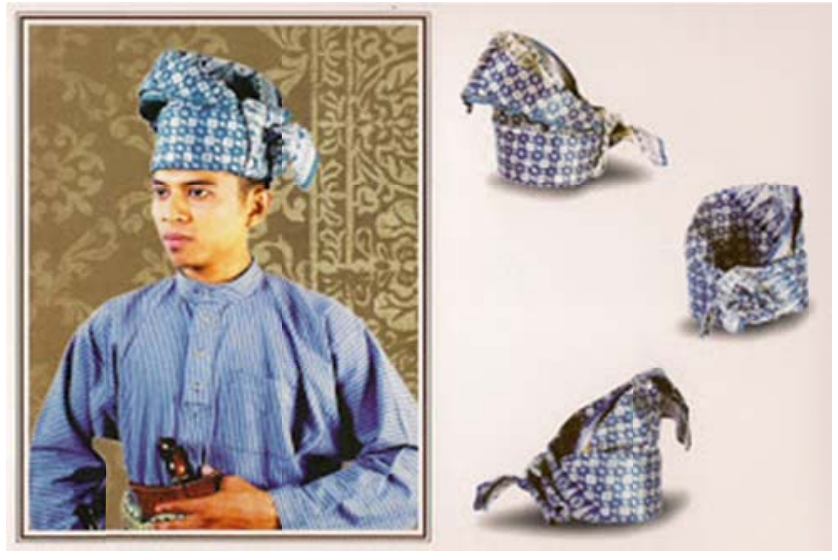

\section{Refleksi Capaian Program}

Setelah sesi pengenalan pemakaian tanjak selesai, sesi berikutnya dilanjutkan dengan sesi mengurai nilai filosofi tanjak. Jumlah mahasiswa yang hadir dalam pengabdian daring adalah 20 orang dan 20 orang peserta tersebut mengisi pretest. Dari hasil pretest ini didapatkan informasi bahwa 20 orang dari 20 orang peserta ( $100 \%$ ) tidak mengenal pemakaian tanjak yang kami kenalkan, Karena ketidaktahuan itu, seluruh peserta $(100 \%)$ merasa perlu untuk mengetahuinya.

Hasil jawaban yang diberikan didapatkan informasi yang beragam tentang manfaat mengetahui pemakaian tanjak. 10 orang peserta (50\%) menjawab mengetahui pemakaian tanjak dapat melestarikan budaya Melayu sebagai wujud kecintaan terhadap budaya Melayu 5 orang peserta (25\%) ini juga memberikan pendapat manfaat pengenalan pemakaian tanjak sebagai jalan menambah pengetahuan dan wawasan, 5 orang peserta lainnya (25\%) mendapat manfaat karena dapat dapat menjabarkan tatacara pemakaian tanjak dan merasakan manfaatnya.

Walaupun awalnya peserta tidak mengenal dan tidak mengetahui pemakaian tanjak Melayu, namun setelah dikenalkan dan dijabarkan seluruh peserta (20 orang) yaitu $(100 \%)$ menyukai pemakaian tanjak dan menyadari perlunya pengenalan pemakaian tanjak bagi mahasiswa, mereka menyadari bahwa mempelajari pemakaian tanjak sangat berguna dalam kehidupan dan pekerjaan, sehingga perlunya pelajaran 
khusus mengenai pemakaian tanjak yang ada di tanah Melayu.

Pengenalan pemakaian tanjak akan semakin baik apabila seluruh elemen masyarakat berperan aktif dalam melestarikan pemakaian tanjak. Pemerintah dengan berbagai kebijakan dan regulasinya yang mendukung pengenalan pemakaian tanjak, salah satunya yang dapat dilakukan adalah pendidikan pemakaian tanjak akan sangat mendukung perkembangan pemakaian tanjak tersebut, Selain itu pengembangan diperguruan tinggi tentu akan sangat diharapkan untuk menarik minat generasi muda mendalami dan mempelajari pemakaian tanjak.

Meningkatkan kualitas maupun kuantitas mahasiswa dengan pemakaian tanjak juga perlu mendapatkan perhatian serius dari pemerintah daerah karena dengan adanya mahasiswa yang berkualitas maka akan mampu mengaplikasikannya kepada pendatang. Melestarikan pemakaian tanjak tidak hanya sebatas menggunakan namun harus mengembangkannya. Kegiatan pengajaran pengenalan pemakaian tanjak sendiri dapat dilaksanakan baik di dunia Pendidikan maupun ditengah-tengah masyarakat.

Pengenalan pemakaian tanjak dapat dilaksanakan untuk pengembangan diri dan profesi agar menjadi lebih profesional dalam melaksanakan pembelajaran mahasiswa. Pengembangan diri adalah penyemaian potensi diri sendiri. Pengembangan diri, ibarat bibit yang perlu disemaikan dulu baru bisa ditanam. Masing-masing dari kita memiliki tanggung jawab untuk ikut melestarikan apa yang telah secara turun-menurun menjadi pengabdian dari para penerus bangsa. Pemakaian tanjak diharapkan dapat lebih dikembangkan dan Semoga pemakaian tanjak tetap lestari.

1. Kegiatan kepada masyarakat mengenai pengenalan pemakaian tanjak dapat dikenalkan dalam setiap bidang kehidupan.

2. Kegiatan pengenalan pemakaian tanjak dapat diajarkan kembali sebagai nilai-nilai luhur masyarakat Riau.

3. Kegiatan ini dapat berlanjut dengan pengenalan pemakaian tanjak yang pada pengabdian masyarakat ditempat lain.

\section{Penutup}

Kemajuan teknologi telah membuat hilangnya Pemakaian tanjak yang benar dan dulunya sangat dibanggakan. Tetapi, tanpa disadari yang sebenarnya Pemakaian tanjak yang benar semakin lama semakin dilupakan dan hilang bersama dengan peredaran jaman. Kalangan anak muda sekarang tidak mengenali Pemakaian tanjak yang benar. Dalam budaya nusantara sangat banyak pakaian adat yang menggunakan ikat atau penutup kepala pada pakaian prianya. Pemakaian tanjak yang seharusnya menjadi kebanggaan dan harusnya di pertahankan sekarang mulai hilang dikarenakan masuknya budaya asing (modern). Kita sebagai warga negara indonesia yang mempunyai hak penuh atas kebudayaan tersebut seharusnya melestarikannya bukan malah mengesampingkannya dengan berbagai alasan. seperti takut dibilang ketinggalan jaman, takut dibilang kupper, katrok, dan lain sebagainya.

Tanjak ini membuktikan identitas suatu budaya, begitu banyak suku di nusantara ini menggunakanya dengan bentuk dan nama yang berbeda beda. Itu semua 
untuk menunjukan identitas budaya dan adat mereka sendiri. Sebagai warga negara yang berbangsa dan berbudaya, mari kita lestarikan Tanjak ini dengan menunjukan pembuatan dan penggunaan tanjak yang benar sesuai kaidah budaya serta adat-istiadat kita masing-masing.

Identitas diri ini dapat dilihat dengan cara pemakaiannya, Tanjak "Dendam tak sudah" tanjak ini biasa khusus hanya di pakai oleh Sultan. Perbedaan hanya terletak pada arah lawi dan lipatnya terdapat 7 jenjang. Tanjak sultan mengarah ke kanan sedangkan "Solok Timbo" mengarah ke kiri yang biasa Digunakan pada perhelatan resmi seperti pernikahan dan acara adat lainya. Cara pemakaian tanjak yang benar dengan jarak 2 jari di atas alis kita dan memposisikan Simpul ketupat palas harus berada diatas telinga kanan kemudian lawinya otomatis akan mengarah ke kiri sampai ke bagian belakang kepala.

Tanjak untuk masyarakat biasa arah lawi kekiri dan solok timbo mengarah kearah kanan sedangkan lipatannya tidak boleh menggunakan tujuh jenjang lipatan, biasanya digunakan pada saat mengikuti acara besar seperti penobatan Datuk dan perkawinan.

Pemakaian tanjak yang lawinya mengarah kebelakang dan solok timbonya mengarah kedepan berarti pemakainya merupakan seorang pelipurlara (Penghibur) yang pada jaman dahulu merupakan orang yang memiliki talenta pandai membuat lucu (humor) untuk menghibur sultan dan para bangsawan pada masa itu. Namun apa bila lawinya mengarah kedepan dan solok timbonya mengarah kebelakang berarti suasana daerah dalam keadaan perang, tanda pemakaian ini merupakan sebuah konsep nilai filosifi keragaman yang wajib masyarakat Melayu mengetahuinya.

Banyak manfaat yang boleh diperoleh dari Pemakaian tanjak seperti mengeratkan hubungan budaya dengan manusia, dan dapat memelihara warisan budaya dari jaman kejaman. Selain itu, daerah Riau dapat mengenalkan Pemakaian tanjak tersebut sebagai salah satu aktivitas yang perlu diperkenalkan kepada wisatawan yang datang ke Riau, ini juga akan menjadi kebanggaan masyarakat Melayu Riau sendiri.

Setelah melakukan kegiatan pengabdian, wawasan peserta pengenalan Pemakaian tanjak. Peserta memahami dan perlunya pengembangan Pemakaian tanjak. Selain itu peserta juga menyadari perlu mengetahui tatacara yang terdapat dalam Pemakaian tanjak karena banyak sekali mengandung nilai-nilai dan tuntunan dalam kehidupan bermasyarakat.

Kegiatan ini dapat dilanjutkan untuk menambah wawasan peserta terhadap Pemakaian tanjak, disamping menyadarkan masyarakat akan pentingnya mengetahui Pemakaian tanjak yang merupakan salah satu identitas dan menandakan keberadaannya. Mengingat jangkauan dengan mencakup peserta yang lebih luas dari berbagai kelompok dan latar belakang sehingga diharapkan pengenalan pemakaian tanjak ini dapat disebarluaskan sehingganya tidak menjadi sesuatu yang tidak dikenal dan difahami masyarakat Riau. 


\section{Daftar Pustaka}

Johan Iskandar, 2018, Destar Alam Melayu, Kuala Lumpur : Akademi Seni Tradisional Warisan Melayu

Putri Manisah, 2019. (Skripsi), Sejarah dan Budaya, Medan : Program Studi Sastra Melayu USU

Sharul Afandy, 2018, https://bebudayamelayu.wordpress.com/2018/04/05/tanjakMelayu-riau-pesisir/ 